\title{
Investigating the Effect of Using Waste Glass on the Properties of Asphalt Concrete Wearing Course Mixture
}

\author{
Roaa Hamed Latief \\ Assistant Lecturer, University of Baghdad-College of Engineering
}

\begin{abstract}
The reuse or recycling of waste materials in different aspects of life is served the objective of sustainability and be beneficial to society. In recent years, a wide variety of waste materials were used in pavement construction. One of these materials is glass that generally produces in large quantities and crushed glass can be considered feasible alternative source of aggregate for asphalt mixture production. This study focused on examining the asphalt mixture properties of wearing course using crushed glass as fine aggregates. Fine crushed glass with various percentages by total weight retained on sieve $2.36 \mathrm{~mm}, 0.3 \mathrm{~mm}$ and $0.075 \mathrm{~mm}$ was used in the study. The results indicate that mixes containing crushed glass had lower Marshall stabilities and tensile strengths compared to conventional mixes. Moreover, the moisture damage resistance of glass-asphalt mixture was acceptable and satisfy the specification requirements for percentages of glass replacement up to 30 percent. Consequently, adding 30 percent of glass by weight of three sizes is the optimal value which represents about 15.6 percent by weight of total aggregate with maximum size $2.36 \mathrm{~mm}$. The study has concluded that recycling and reuse of waste glass in asphalt mixture could be possible and yield a result which satisfies the specification of asphalt concrete wearing course mixtures.
\end{abstract}

Keywords: waste glass, Marshall properties, stripping, tensile strength

\section{Introduction}

Waste material is one of the serious problems around the world because of the insufficient capacity of landfills, environmental pollution, and limited alternatives for recycling [1]. The waste materials can be categorized as follows: industrial wastes, municipal/domestic wastes, and mining wastes [2]. Reuse or recycle these materials in different aspects such as building constructions and pavement help to conserve natural resources and decrease environmental pollution. In recent years, the uses of different recycled materials are taken into consideration by many researchers to improve the performance requirements of asphalt mixtures. As a result, some of the waste materials were used in pavements construction like plastic bottles, scrap tires, glass, and electronic debris. Recycling of waste materials in pavement construction should be supported and encouraged. However, it is necessary to address the engineering concerns, environmental concerns and economic concerns before any widespread employ of these materials. Asphalt mixture containing a waste material should present acceptable performance properties as the conventional mixture. It should also be environmentally safe both for the first construction and future recyclability [3]. One of the solid waste material is glass that generally produces in large quantities and can be recycled for several times without any change in its properties [4]. Every year, about ten million tons of waste glass have been generated in the world and that amounts to nearly $3 \%$ to $5 \%$ of household waste [5].

\section{Literature Review}

Waste glass is one of the nonmetallic and inorganic materials and can neither be incinerated nor decomposed. Hence, it has been used in pavement construction as an aggregate replace in HMA paving [3]. The first trial to use glass-asphalt pavement in the late of 1960's. Asphalt mixture containing waste glass is known as "glasphalt" mixture [6]. Between 1969 and 1988, glass-asphalt mixtures were successfully mixed and placed in at least 45 locations in the U.S.A and Canada. However, most glass-asphalt has been placed on city streets, driveways and parking lots, also, not applied on highvolume and high-speed highways [7]. The Florida Department of Transportation (DOT) was conducted laboratory tests of asphaltic mixtures with glass which is used as coarse and fine aggregate replacement. Larger glass particles in the asphaltic mix, especially those that are elongated, have a propensity to smash during pavement construction and in-service due to traffic loads and that may cause a decrease in skid resistance, also it may abrade the tires when application the glass-asphalt on wearing course layer. Large glass particles should thus be avoided, so the maximum size of broken crushed glass must not exceed 4.75 $\mathrm{mm}$ [8]-[14]-[9]. While, the smaller glass particles have more fragmentized and coarse surface areas, which is more effective concerning adhesion between glass particles and asphalt [9]. DOT recommends that glass content must be less than $15 \%$, with $100 \%$ passing sieve $3 / 8$ ", and not exceed $8 \%$ passing sieve No. 200 [10]-[11]. In addition, glass content from $10 \%$ to $15 \%$ in asphaltic mixture with particles size less than $4.75 \mathrm{~mm}$ presents the best performance for pavements [12]. Further, the stiffness modulus of asphalt concrete will decrease when using glass content more than the allowed limit $(15 \%)$ and also smoothness of glass particles surface may cause stripping of asphalt binder [13].

Glass- asphalt mixture tends to retain heat more than conventional mixture. Moreover, it can be shiny due to exposure to sunlight or headlights, also, after rain, it dries faster than conventional mixture. The economic feasibility study of using glass-mixture depends on local conditions for

Volume 6 Issue 12, December 2017 


\section{International Journal of Science and Research (IJSR) \\ ISSN (Online): 2319-7064 \\ Index Copernicus Value (2016): 79.57 | Impact Factor (2015): 6.391}

recycling, crushing and haul cost, landfill, and traditional asphalt paving cost [15].

The major concern of using glass in pavement mixtures is the lack of adhesion and absorption of asphalt binder by glass particles and the hydrophilic properties of glass that contribute to a deterioration of glass-asphalt pavements due to moisture damage. The addition $1 \%$ to $3 \%$ of hydrated lime acts as an anti-stripping agent can help minimize potential of stripping problems [16]-[17]-[18]-[14]

\section{Objective of the Study}

The main objectives of this study are: -

- Examining the asphalt mixture properties when different percentages of waste glass were added as substitution percentage of virgin fine aggregate and compared with properties conventional mixture.

- Determination the maximum allowable percentage of recycled crushed glass that could be safely added to an aggregate used as a wearing course without weakening pavement performance.

\section{Material}

Fine and coarse aggregates selected for this study were sourced from Al-Nibaie quarry, located in the north of Baghdad-Iraq. The asphalt cement used was AC (40-50), supplied from Al- Dora oil refinery in the south-west of Baghdad-Iraq. Limestone powder was used as filler. The resistance of glass-asphalt mixture against water can be improved by adding $2 \%$ of hydrated lime as anti-stripping agent, which is recommended in the previous studies. Limestone and hydrated lime were obtained from lime factory in Karbala, located in the south-east of Iraq. All these materials were tested in the laboratory and evaluated with the local specification limitations [19]. Table (1) shows the engineering properties of materials used in this work.

Table 1: Materials properties

\begin{tabular}{|c|c|c|}
\hline Test & Value & $\begin{array}{c}\text { Local } \\
\text { Specification }\end{array}$ \\
\hline \multicolumn{3}{|l|}{ Asphalt Cement } \\
\hline Penetration, $0.1 \mathrm{~mm}$ & 45 & $40-50$ \\
\hline Specific Gravity, $\mathrm{g} / \mathrm{cm}^{3}$ & 1.03 & - \\
\hline Ductility, $\mathrm{cm}$ & 128 & $>100$ \\
\hline Flash Point, ${ }^{0} \mathrm{C}$ & 279 & $>232$ \\
\hline Fire Point, ${ }^{0} \mathrm{C}$ & 315 & - \\
\hline Softening Point, ${ }^{0} \mathrm{C}$ & 52 & - \\
\hline \multicolumn{3}{|l|}{ Coarse Aggregate } \\
\hline Apparent Specific Gravity, $\mathrm{g} / \mathrm{cm}^{3}$ & 2.673 & - \\
\hline Bulk Specific Gravity, $\mathrm{g} / \mathrm{cm}^{3}$ & 2.631 & - \\
\hline Water Absorption, $\%$ & 0.21 & - \\
\hline Los Angeles Abrasion, $\%$ & 18.5 & $30 \operatorname{Max}$ \\
\hline Soundness, $\%$ & 3.82 & $18 \operatorname{Max}$ \\
\hline \multicolumn{3}{|l|}{ Fine Aggregate } \\
\hline Apparent Specific Gravity, $\mathrm{g} / \mathrm{cm}^{3}$ & 2.682 & - \\
\hline Bulk Specific Gravity, g/cm ${ }^{3}$ & 2.63 & - \\
\hline
\end{tabular}

\begin{tabular}{|l|c|c|}
\hline Water Absorption, \% & 0.34 & - \\
\hline Angularity,\% & 55.42 & - \\
\hline Limestone Powder & 2.74 & - \\
\hline Specific Gravity, g/cm ${ }^{3}$ & 96 & $70-100$ \\
\hline Passing Sieve No.200, \% & \multicolumn{2}{|l|}{} \\
\hline Hydrated Lime & 2.42 & - \\
\hline Specific Gravity, g/cm ${ }^{3}$ & 94 & - \\
\hline Passing Sieve No.200, \% &
\end{tabular}

The waste glass must be properly cleaned from the strange materials like labels, plastic, food residue, and metal. Glass used in this study is produced from crushing domestic waste glass (bottles, cans food, and jars) by using Los Angeles machine and then screening to a proper size, had a $2.36 \mathrm{~mm}$ maximum size. Figure (1) displays a photograph of crushed glass sizes used in this study. The crushed glass was added to the mixes replacing some of the fine aggregate in three sizes, that are $2.36 \mathrm{~mm}, 0.3 \mathrm{~mm}$ and $0.075 \mathrm{~mm}$ with glass replacement percentage of $15 \%, 30 \%, 45 \%$, and $60 \%$ by total weight of each size.

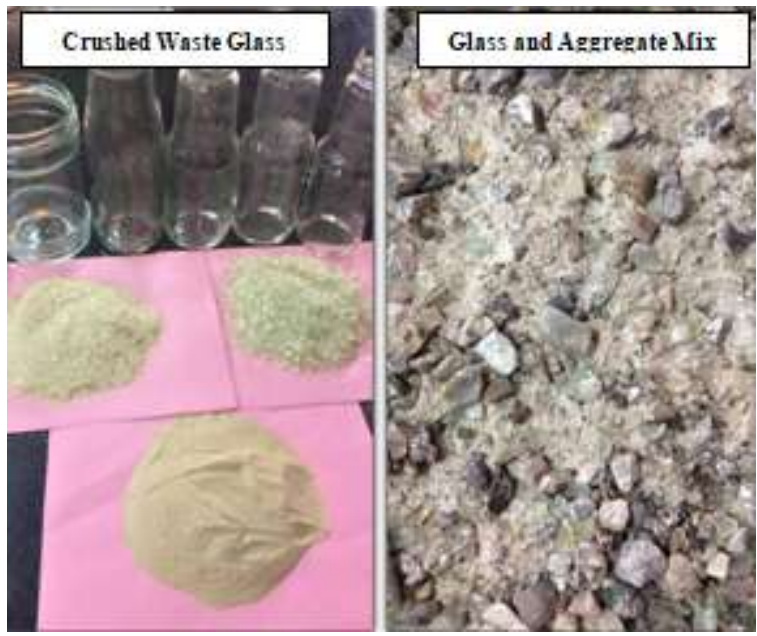

Figure 1: Crushed glass

\section{Mix Gradation}

The aggregate gradation used is according to local specification requirements [19] for the wearing course with nominal maximum size of $12.5 \mathrm{~mm}\left(1 / 2^{\prime \prime}\right.$ in) as shown in table (2) and plotted in figure (2).

Table 2: Aggregate gradation for wearing course

\begin{tabular}{|c|c|c|c|}
\hline \multirow[b]{2}{*}{$\begin{array}{c}\text { English } \\
\text { Sieves }\end{array}$} & \multirow{2}{*}{$\begin{array}{c}\text { Standard } \\
\text { Sieves } \\
(\mathrm{mm})\end{array}$} & \multicolumn{2}{|c|}{$\%$ Passing by Weight } \\
\hline & & $\begin{array}{c}\text { Selected } \\
\text { Gradation } \\
\end{array}$ & $\begin{array}{c}\text { Local } \\
\text { Specification }\end{array}$ \\
\hline $3 / 4 "$ & 19 & 100 & 100 \\
\hline $1 / 2 "$ & 12.5 & 95 & $90-100$ \\
\hline $3 / 8^{\prime \prime}$ & 9.5 & 83 & $76-90$ \\
\hline No.4 & 4.75 & 59 & $44-74$ \\
\hline No.8 & 2.36 & 37 & $28-58$ \\
\hline No.50 & 0.300 & 13 & $5-21$ \\
\hline No.200 & 0.075 & 7 & $4-10$ \\
\hline
\end{tabular}




\title{
International Journal of Science and Research (IJSR) \\ ISSN (Online): 2319-7064
}

Index Copernicus Value (2016): 79.57 Impact Factor (2015): 6.391

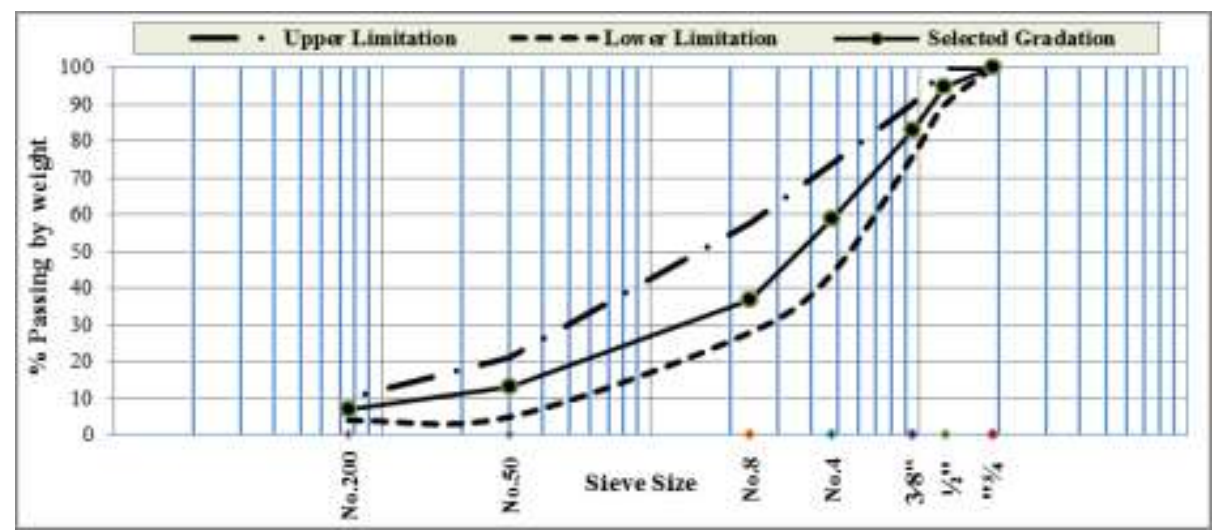

Figure 2: Aggregate gradation curve for wearing course

\section{Experimental Work}

Laboratory tests, such as Marshall test, indirect tensile test, and modified Lottman test, are used to assess the properties of the wearing asphalt mixture with waste glass addition as fine aggregate replacement. The same asphalt content of $5 \%$ is used for glass-asphalt and conventional mixtures

\subsection{Marshall Test}

The specimens were prepared, mixed, and compacted in accordance with the Marshall test method ASTM D6927-15. The heated asphalt, at a temperature up to $145^{\circ} \mathrm{C}$, was added to the heated blended aggregates and then mixed for at least 3 minutes until a homogenous mix is achieved. Loose asphalt mixes were compacted to a height of $63.5 \mathrm{~mm}$ and a diameter of $101.6 \mathrm{~mm}$ (Marshall cylindrical molds). Marshall samples constructed using 75 blows of Marshall Hammer on each side of the mold. Figure (3) illustrates some of Marshall Specimens.

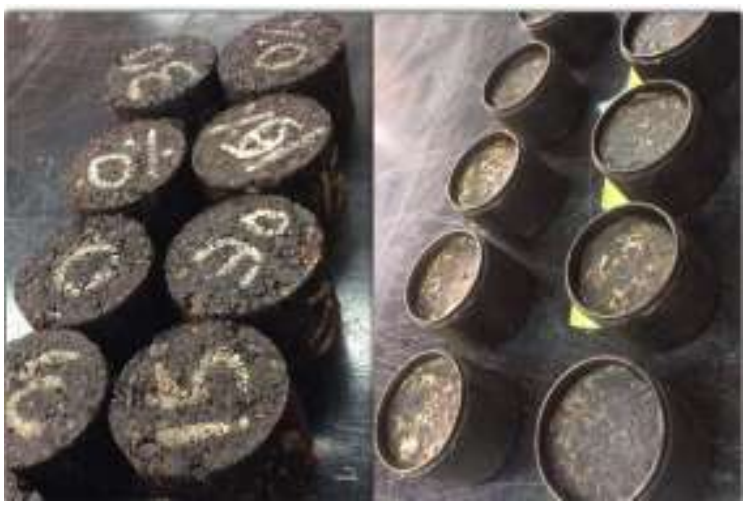

Figure 3: Marshall specimens

Samples were immersed in water bath for 30-40 minutes at a temperature of $60{ }^{\circ} \mathrm{C}$ and then tested by applying a vertical diametrically load at a constant loading rate of 50.8 $\mathrm{mm} /$ minute which is performed by means of Marshall apparatus until the peak load is attained, as shown in figure (4).

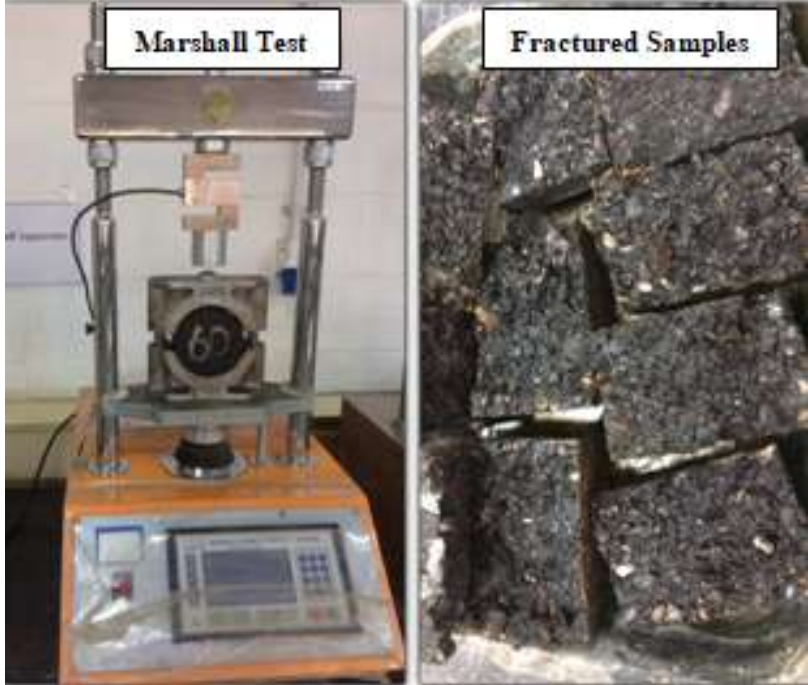

Figure 4: Marshall specimens testing

The Marshall quotient (MQ, KN/mm), determined as the ratio of stability value to flow value which represents an approximation of the ratio of load to deformation under specific conditions of the test and that may be used as a measure of the asphalt mixture resistance to permanent deformation in service [20].

\subsection{Indirect Tensile Strength Test (ITST)}

Indirect tensile test (ITST) were conducted in accordance with ASTM D6931-07 specification. Marshall samples were tested by applying load diametrically in compression with a constant rate of $50.8 \mathrm{~mm} /$ minute by using Versa tester machine. After the sample fractured, the peak load (P) was recorded. Figure (5) represents the indirect tensile strength test.

\section{Volume 6 Issue 12, December 2017}

\author{
www.ijsr.net
}




\section{International Journal of Science and Research (IJSR) \\ ISSN (Online): 2319-7064}

Index Copernicus Value (2016): 79.57 | Impact Factor (2015): 6.391

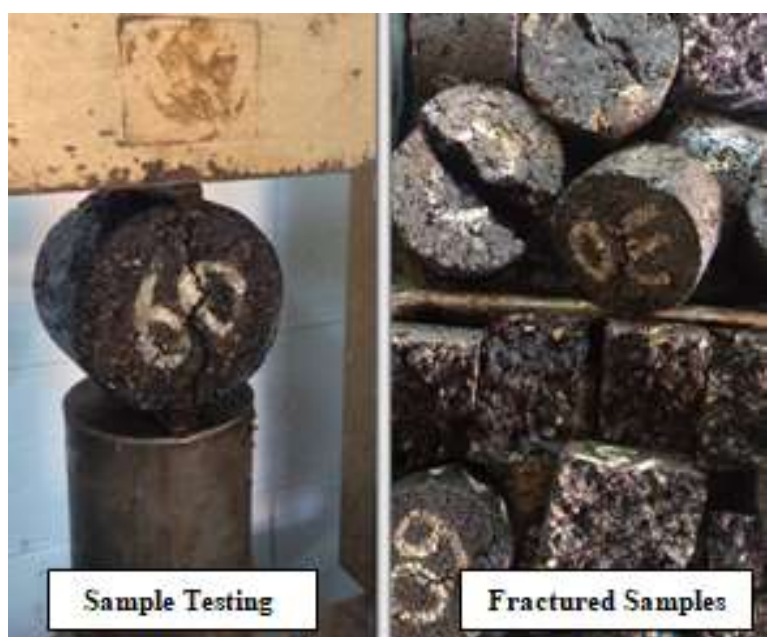

Figure 5: Indirect tensile strength test

The ITS value can be determined as follow:

$$
I T S=\frac{2000 * P}{\pi * h * d}
$$

Where:

ITS = Indirect Tensile Strength, Kpa

$\mathrm{P}=$ Maximum Applied Load, $\mathrm{N}$

$\mathrm{h}=$ Sample Height, $\mathrm{mm}$

$\mathrm{d}=$ Sample Diameter, $\mathrm{mm}$

\subsection{Modified Lottman Test (MLT)}

Modified Lottman test (MLT) was performed accordance with AASHTO T 283. MLT has been used to identify the moisture damage resistance of asphalt concrete mixture. Moisture damage or stripping is considered one of the main causes of distresses in the asphalt pavement layers. The Marshall specimens were divided into two sets: the first is unconditioned set while the second is conditioned set. The conditioned set is vacuum saturated with water and then placed in a freezer for a minimum 16 hours at $0{ }^{0} \mathrm{C}$ temperature (freezing cycle). The samples are then placed in water bath at a temperature of $60{ }^{\circ} \mathrm{C}$ for 24 hours (thawing cycle). After one freezing and thawing cycle, the samples were placed in water bath for 2 hours at a temperature of 25 ${ }^{0} \mathrm{C}$ and tested by Versa tester machine with applying a constant loading rate of $50.8 \mathrm{~mm} /$ minute. Figure (6) presents the stages of modified lottman test for one group of samples. The maximum load of sample fracture was recorded.
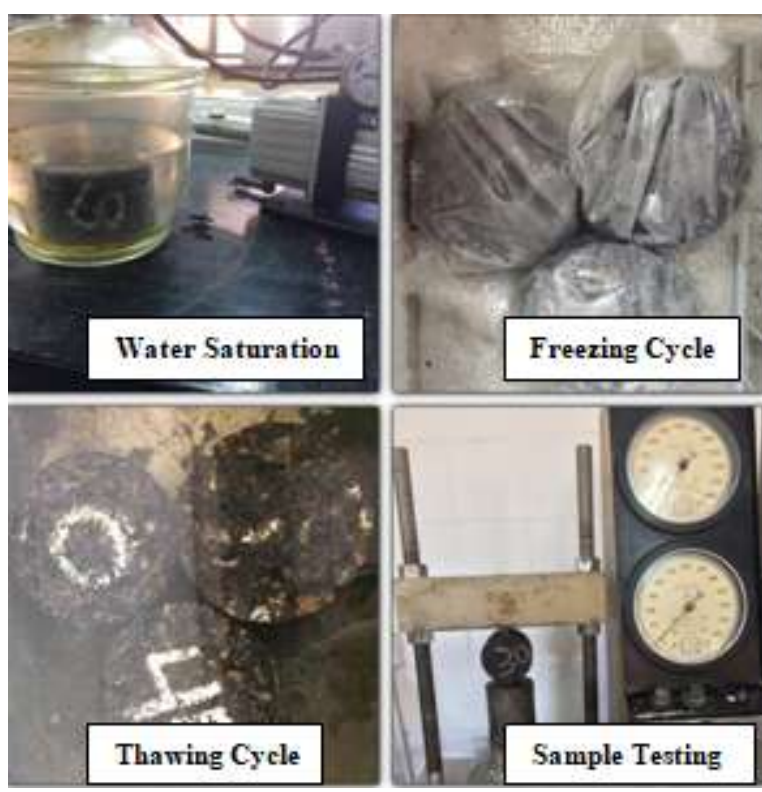

Figure 6: Modified lottman test

The average tensile strength of conditioned specimens is compared to the average tensile strength of unconditioned specimens to determine tensile strength ratio (TSR) as below:

$$
T S R=\frac{S 1}{S 2} * 100
$$

Where:

TSR $=$ Tensile Strength Ratio, \%

$\mathrm{S}_{1}=$ Strength of Conditioned Set, Kpa

$\mathrm{S}_{2}=$ Strength of Unconditioned Set, Kpa

\section{Tests Results}

A series of asphalt mixtures samples made using various percentage of recycled glass. All samples tested using Marshall test, Indirect tensile strength test, and moisture damage test. Comparisons were performed between the conventional mix, which contained no glass, and the mixes with adding crushed glass.

\subsection{Marshall Properties}

Marshall mixtures were designed to meet the requirements of stability, flow and voids recommends by the local specification for wearing asphalt course [19]. Table (3) lists Marshall test results for glass-asphalt and conventional mixes and the specification limit.

Table 3: Marshall properties

\begin{tabular}{|c|c|c|c|c|c|c|}
\hline Percent Glass & 0 & 15 & 30 & 45 & 60 & $\begin{array}{c}\text { Local } \\
\text { Specification }\end{array}$ \\
\hline Stability, KN & 12.7 & 10.3 & 9.64 & 9.13 & 7.7 & $8 \mathrm{~min}$. \\
\hline Flow, mm & 3.91 & 3.89 & 3.81 & 3.81 & 3.6 & $2-4$ \\
\hline $\begin{array}{c}\text { Unit Weight, } \\
\text { g/cm }\end{array}$ & 2.336 & 2.324 & 2.293 & 2.261 & 2.232 & - \\
\hline V.T.M, \% & 4.23 & 3.91 & 3.58 & 2.98 & 2.67 & $3-5$ \\
\hline V.M.A, \% & 15.15 & 14.86 & 14.2 & 14.07 & 13.81 & 14 min. \\
\hline V.F.A, \% & 72.1 & 73.7 & 74.8 & 78.8 & 80.7 & - \\
\hline
\end{tabular}

After calculations were made, Marshall stability values decreased approximately by $19-39 \%$ when $15 \%$ to $60 \%$ of

Volume 6 Issue 12, December 2017 www.ijsr.net 


\section{International Journal of Science and Research (IJSR) \\ ISSN (Online): 2319-7064}

Index Copernicus Value (2016): 79.57 | Impact Factor (2015): 6.391

the natural fine aggregate $(2.36,0.3$, and $0.075 \mathrm{~mm}$ sizes) was replaced with crushed fine glass. In spite of that, Marshall stability for all glass-asphalt mixtures within local specification requirement, except stability value for glass content of $60 \%$ which is below the minimum criteria $8 \mathrm{KN}$. The results were viewed in graphical form in figure (7).

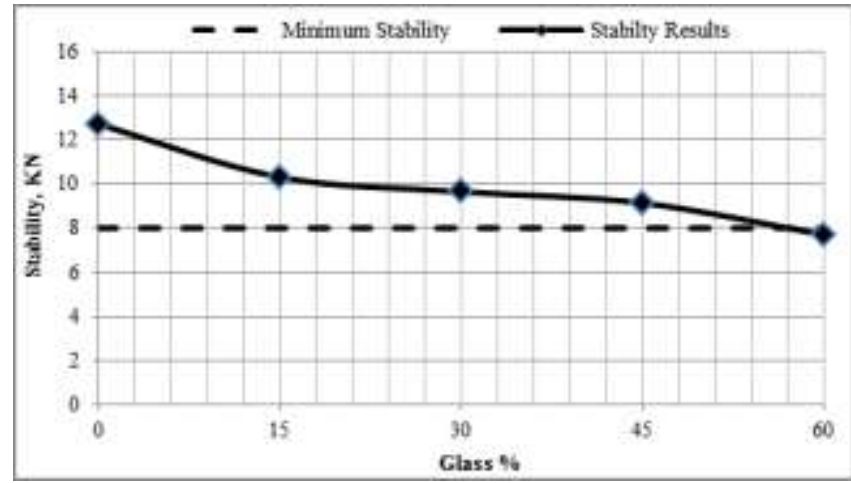

Figure 7: Effect of glass addition on Marshall stability

According to results in figure (8), The vertical deformation of the sample is represented by flow value. The flow for glass-mixtures is still in the range of specification criteria (2$4 \mathrm{~mm}$ ) for all glass contents.

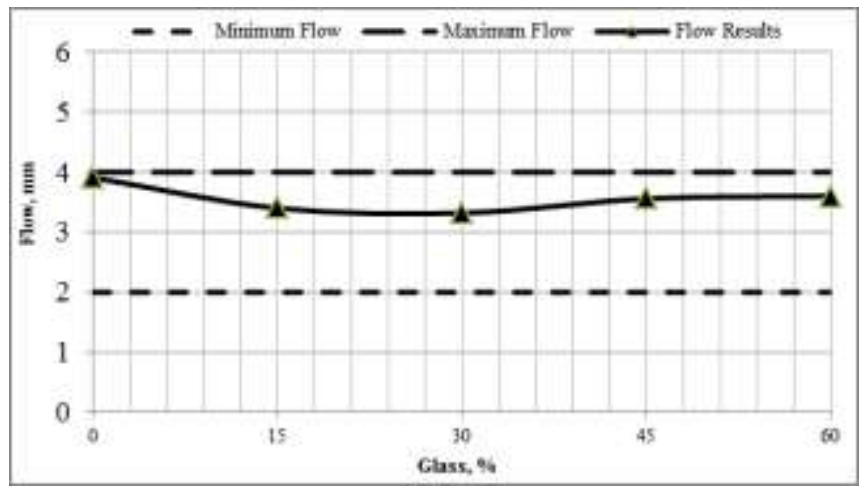

Figure 8: Effect of glass addition on flow value

The unit weight of asphalt mixes tends to decrease when crushed waste glass is added and increased the replacement content of glass instead of natural fine aggregate, primarily because of the lower specific gravity of the crushed glass material, as shown in figure (9). Also, the use of recycled glass leads to decrease the voids in the mineral aggregate (V.M.A) and air voids (V.T.M) in Marshall mixes, therefore, asphalt content will also be reduced. The possible cause of these trends is the surface texture and particle shape of the crushed glass which differs substantially than the natural aggregate. Furthermore, the voids filled with asphalt (VFA) increases with an increase in the content of crushed glass due to the fact that glass material has lower absorption for asphalt, the previous results are displayed in figure $(10,11$ $\& 12)$.

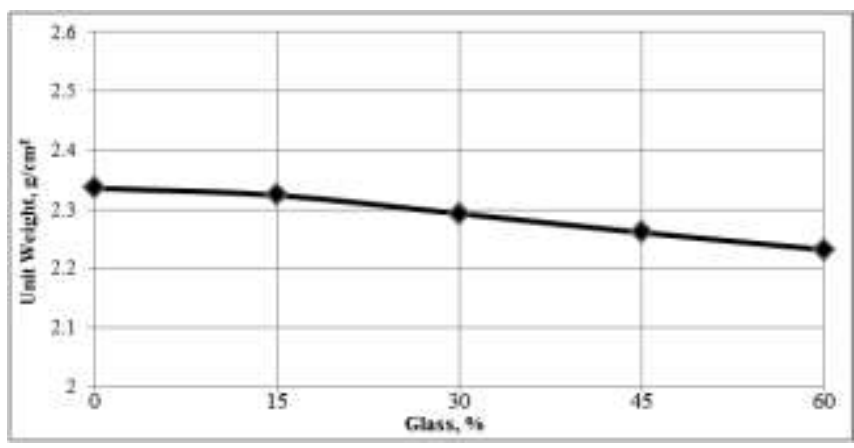

Figure 9: Effect of glass addition on unit weight

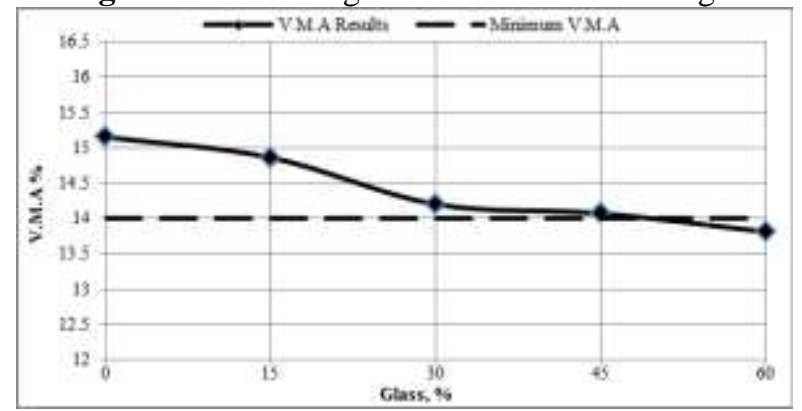

Figure 10: Effect of glass addition on V.M.A

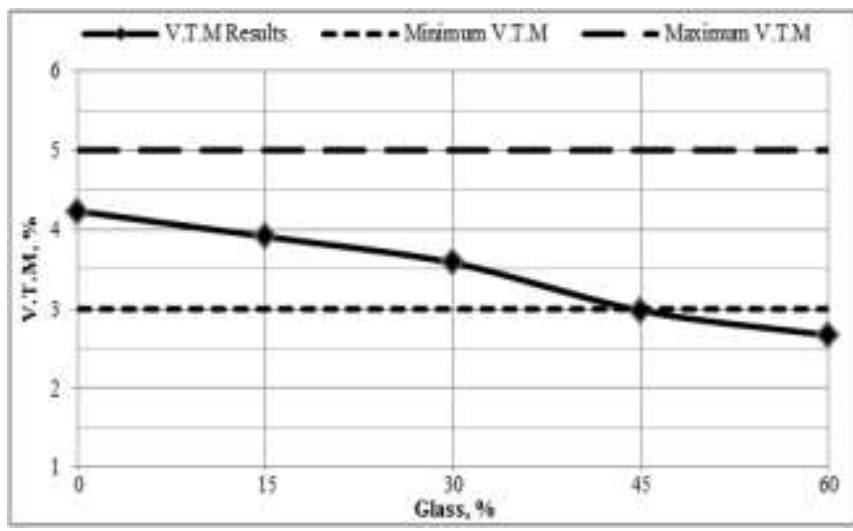

Figure 11: Effect of glass addition on V.T.M

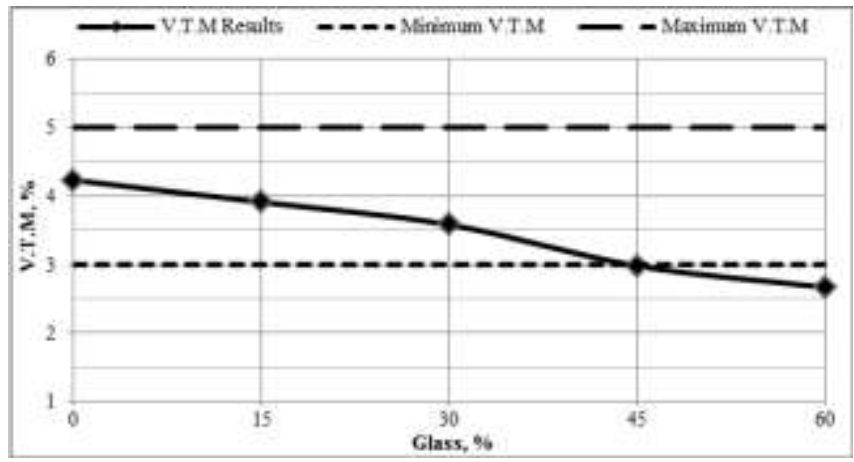

Figure 12: Effect of glass addition on V.F.A

Marshall quotient (MQ) decreases with the increase of glass content. Therefore, the highest value of MQ is for conventional mix when no glass is added in the mix. Furthermore, the trend of MQ was sharply decreased when glass addition exceeds $30 \%$ by weight of three sizes. MQ results are illustrated in figure (13).

Volume 6 Issue 12, December 2017 www.ijsr.net 


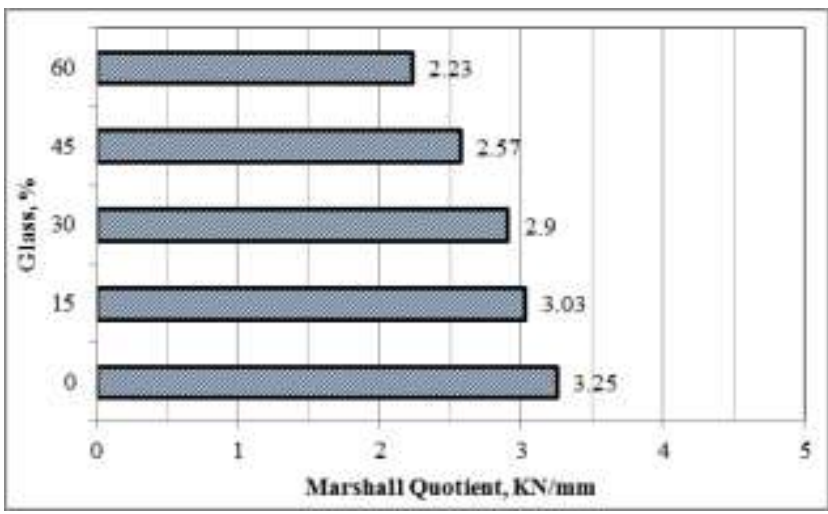

Figure 13: Effect of glass addition on Marshall quotient

\subsection{Indirect Tensile Strength}

A measure of cohesive strength is the indirect tensile strength. Based on results in figure (14), the tensile strength of conventional samples is higher than that of the glassasphalt sample. . Moreover, the indirect tensile strengths were slightly decreased at the addition of recycled glass up to $30 \%$. In other words, the tensile strength of glass-asphalt mix with $30 \%$ of glass replacement is about $5.1 \%$ lesser than that of conventional mix while the reduction in tensile strength for glass contents $45 \%$ and $60 \%$ are about $20.8 \%$ and $26.5 \%$ respectively.

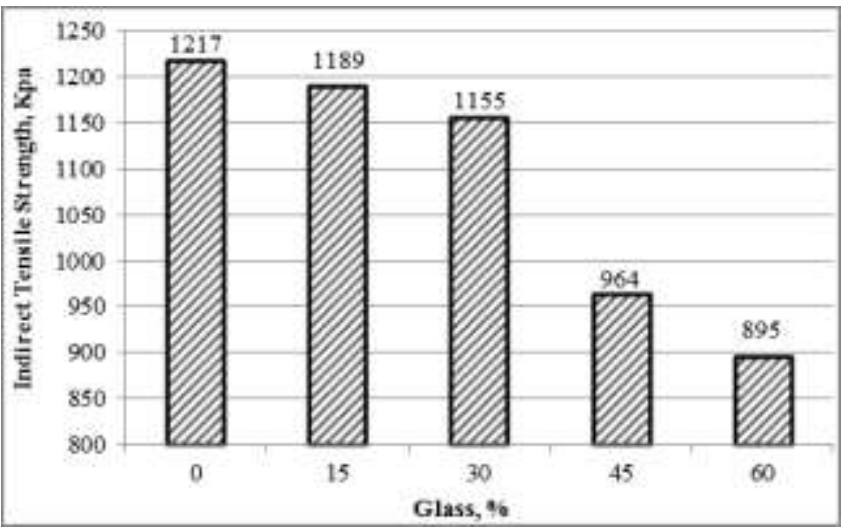

Figure 14: Effect of glass addition on tensile strength

\subsection{Moisture Damage Performance}

Specification requirement of AASHTO R30 use a minimum value of TSR about $80 \%$ in the moisture damage sensitivity test. It is seen in figure (15) that in the average TSR results generally declined as the glass content was increased, accordingly, the glass-asphalt mix was prone to moisture damage more than conventional mix. However, results found that the moisture damage resistance of glass-asphalt mixture was acceptable and satisfies the specification requirements (minimum TSR-80\%) for percentages of glass replacement up to 30 percent.

It was expected that TSR results for glass-mixtures less than a minimum criterion $(80 \%)$ due to the smoothness of glass surface but the result was different. Because adding hydrated lime to glass-mixture was effective in maintaining a certain level of stripping resistance. However, by visual inspection, some separation was observed at the asphalt/glass interface.

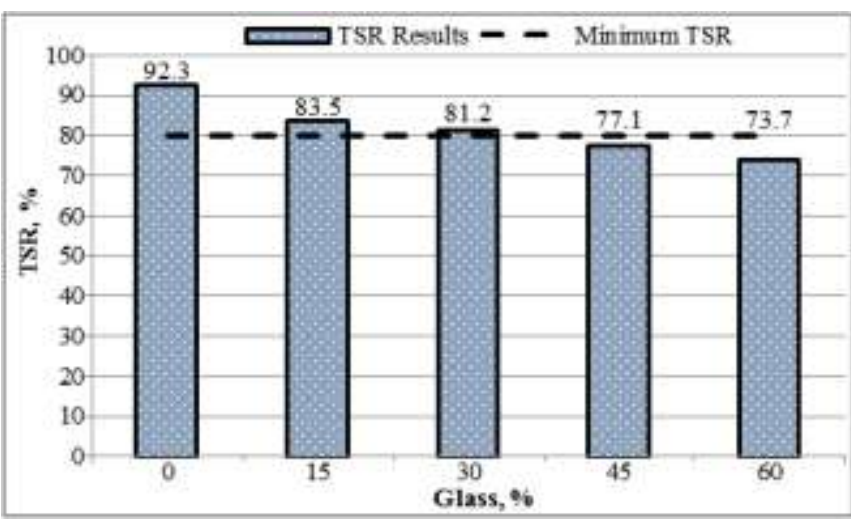

Figure 15: Effect of glass addition on moisture damage

\subsection{Maximum Glass Content}

It is noticed from tests results that Marshall flow and Marshall stability for glass-asphalt mixtures with different glass content satisfy the local specification requirement except the stability value at $60 \%$, it's below the minimum specifications limit. Also, glass contents for $45 \%$ and $60 \%$ out of specification range for TSR, V.M.A and V.T.M values. Subsequently, by using various percentages of crushed glass of $15 \%, 30 \%, 45 \%$ and $60 \%$, by total weight of three sizes, adding $30 \%$ of glass is the optimal value which satisfied all the requirements as per the specification limits, as shown in table (4).

Table 4: Properties of glass-asphalt mixture for maximum glass content

\begin{tabular}{|c|c|c|}
\hline \multicolumn{3}{|c|}{ Maximum Glass Content $=30 \%$} \\
\hline Property & Value & $\begin{array}{c}\text { Local } \\
\text { Specification, [19] }\end{array}$ \\
\hline Stability, KN & 9.64 & 8 min. \\
\hline Flow, mm & 3.81 & $2-4$ \\
\hline Unit Weight, g/cm ${ }^{3}$ & 2.293 & - \\
\hline V.T.M, \% & 3.58 & $3-5$ \\
\hline V.M.A, \% & 14.2 & 14 min. \\
\hline V.F.A, \% & 74.8 & - \\
\hline Marshall quotient, MQ, KN/mm & 2.9 & - \\
\hline Indirect Tensile Strength, Kpa & 1155 & - \\
\hline Tensile Strength Ratio, \% & 81.2 & 80 min. \\
\hline \multicolumn{2}{|c|}{ * AASHTO R30 specification requirement } \\
\hline
\end{tabular}

\section{Conclusion}

The aim of this study was to assess the laboratory behavior of glass-asphalt mixture. Based on the laboratory evaluation adopted in this study, the following conclusions are made:

1) The conclusions of this study depend on specific gradation and type of glass. Another gradation of glass or different source may produce different results.

2) Marshall stability for all glass-asphalt mixtures within local specification requirement, except stability value for glass content of 60 percent which is below the minimum criteria, while, the flow is still in range of specification criteria for all glass contents.

3) The unit weight of glass-asphalt mixes tends to decrease when crushed waste glass is increased, primarily because of the lower specific gravity of the crushed glass material. 


\section{International Journal of Science and Research (IJSR) \\ ISSN (Online): 2319-7064}

Index Copernicus Value (2016): 79.57 | Impact Factor (2015): 6.391

4) The use of crushed glass in asphalt mixture cause a reduction in VMA and VTM values and increase VFA therefore, asphalt content will be reduced.

5) The values of indirect tensile strengths and Marshall quotient were sharply decreased when glass content exceeds 30 percent by total weight of three sizes.

6) The moisture damage resistance of glass-asphalt mixture was acceptable and satisfies the specification requirements for percentages of glass replacement up to 30 percent. Also, adding 2 percent of hydrated lime provides good resistance to water damage and reduces visible stripping.

7) Adding 30 percent of glass by total weight of three sizes is the optimal value which represents about 15.6 percent by weight of total aggregate with maximum size $2.36 \mathrm{~mm}$.

8) Using waste glass in asphalt mixture production will decrease environmental pollution and save natural resources for raw materials.

\section{References}

[1] J. Warren, "The Use of Waste Materials in Hot Mix Asphalt," Special report 152, NAPA, June 25, 1991.

[2] W. C. Ormsby, and D. G. Fobs, "Use of Waste and ByProducts in Highway Construction," Paper presented at the Annual Meeting of TRB, January 1991.

[3] P. S. Kandahl, "Waste Materials in Hot Mix Asphalt- an Overview. National Center for Asphalt Technology," Report 92-06, Presented at the ASTM Meeting in Miami, Florida, Auburn University, Alabama, pp. 10-12, December 1992.

[4] "Markets for recovered glass", United States Environmental Protection Agency, Policy, Planning and Evaluation, 1992.

[5] S. Wu, W. Yang, and Y. Xue, "Preparation and Properties of Glass-Asphalt Concrete," Key Laboratory for Silicate Materials Science and Engineering of Ministry of Education, China, Wuham, University of Technology, 2004.

[6] W. R. Malisch, D. E. Day, and B. G. Vixson, "Use of Domestic Glass for Urban Paving: Summary Report," Report no. EPA/670/2-75-053, Missouri University, Rolla, 1975.

[7] D. A. Larsen, "Feasibility of Utilizing Waste Glass in Pavements." Report No. 343-21-89-6, Connecticut Department of Transportation, June 1989.

[8] D. Byrum, "Asphalt Pavement From Glass and Rubber Wastes," Rural and Urban Roads, Volume 9, No. 12, 1971.

[9] M. M. Marti, and P. E. A. Mielke, "Synthesis Of Asphalt Recycling In Minnesota," Synthesis Report 2002-32, Minnesota Local Road Research Board, 2002.

[10]H. F. Waller, "Use of Waste Materials in Hot-Mix Asphalt," ASTM STP 1193, American Society of Testing Materials, Philadelphia, pp.117-125, 1993.

[11]R. C. West, G. C. Page, and K. H. Murphy, "Evaluation of Crushed Glass in Asphalt Paving Mixtures," Report No. FL/DOT/SMO/91-388, State of Florida Department of Transportation, April, 1991.

[12] M. Arabani, "An Investigation on Effective Parameters on Fatigue Behavior of Asphalt Pavements Containing
Waste Glass," 1st professional and practical congress of hot mix asphaltse, Iran University of Science and Technology, 2008.

[13] M. Arabani, "Effect of Glass Cullet on the Improvement of the Dynamic Behavior of Asphalt Concrete," Resources, Construction and Building Materials International Journal, Volume 25, No. 3, pp. 1181-1185, 2011.

[14] Y. R. Malisch, D. E. Day, B. G. Vixson, and K. O. Anderson, "Use of Domestic Waste Glass as Aggregate in Bituminous Concrete," Highway Research Record No. 307, Highway Research Board, Washington, D. C., 1970.

[15]D. Delbert, and S. Robert, "Glasphalt Paving Handbook," University of Missouri-Rolla, 53 pages, 1994.

[16] C. S. Hughes, "Feasibility of Using Recycled Glass in Asphalt," Report VTRC90-R3, Virginia Transport Research Council, Charlottesville, 1990.

[17] L. S. David, C. J. Newton, and W. A. Keith, "Used of Recycled Materials in Highway Construction," Technical report, No. WA-RD 252.1, Washington State Department of Transportation, 1992.

[18] Y. A. Sussman, "Reclaimed Glass Aggregate Asphalt Pavement," Highway Focus, volume 8, No. 2, 1976.

[19] SCRB, General Specification for Roads and Bridges, Section R/9, Hot-Mix Asphalt Concrete Pavement, Revised Edition, State Corporation of Roads and Bridges, Ministry of Housing and Construction, Republic of Iraq, 2003.

[20]Zoorob, and L. Suparma, "Laboratory Design and Investigation of the Properties of Continuously Graded Asphaltic Concrete Containing Recycled Plastics Aggregate Replacement (Plastiphalt)," Cement and Concrete Composites, Volume 22, No. 4, PP. 233-242, 2000.

\section{Author Profile}

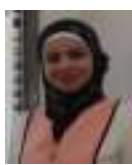

Roaa Hamed Latief Assistant Lecturer at the Civil Engineering Department, College of Engineering, University of Baghdad, Iraq. She received the B.S. and M.S. degrees in Civil Engineering from Civil Engineering Department, College of Engineering, University of Baghdad in 2007 and 2014, respectively. 